\title{
Awareness and Practices of Sanitary Latrine Usage and Environmental Cleanliness in Rural Etawah, Uttar Pradesh
}

\author{
Debora J. Mathew ${ }^{1}$, Sandip Kumar², Kirti Jaiswal ${ }^{3}$, Prashant Kumar Bajpai ${ }^{4}$, Nishant Singh ${ }^{5}$, Nawazish Ali6 \\ ${ }^{1}$ Department of Community Medicine, Uttar Pradesh University of Medical Sciences, Saifai, Etawah, Uttar \\ Pradesh, India. ${ }^{2}$ Department of Community Medicine, Uttar Pradesh University of Medical Sciences, Saifai, \\ Etawah, Uttar Pradesh, India. ${ }^{3}$ Department of Physiology, Uttar Pradesh University of Medical Sciences, \\ Saifai, Etawah, Uttar Pradesh, India. ${ }^{4}$ Department of Community Medicine, Uttar Pradesh University of \\ Medical Sciences, Saifai, Etawah, Uttar Pradesh, India. ${ }^{5}$ Department of Community Medicine, Uttar Pradesh \\ University of Medical Sciences, Saifai, Etawah, Uttar Pradesh, India. ${ }^{6}$ Department of Community Medicine, \\ Uttar Pradesh University of Medical Sciences, Saifai, Etawah, Uttar Pradesh, India.
}

\section{ABSTRACT}

\section{BACKGROUND}

The Sustainable Development Goal 6 aims to achieve adequate and equitable sanitation and hygiene for all and ending open defecation by 2030 . Construction of household toilets does not always translate into its usage in rural areas, as open defecation has become a long-ingrained habit. The Swachta Status Report 2016 states that the majority of people in India (52.1\%) practiced open defecation, $24.4 \%$ of households disposed of garbage in the nearby agricultural field, while $15.1 \%$ threw garbage around the house.

\section{METHODS}

It was a community-based cross-sectional study conducted in four villages of a selected block of the district. A total of 150 households were included in the study. Data was collected using a pre-designed semi-structured questionnaire and information was collected regarding their background characteristics, awareness, practices of sanitary latrine usage, and environmental cleanliness.

\section{RESULTS}

Out of a total of 150 participants, 54\% practiced open-air defecation. The drainage system of most households was an open pucca type (73.3\%), while garbage was disposed of at a common spot outside the homes in 48.7\%. Most respondents were unaware that diseases can be caused by inadequate sanitation (55.3\%). A higher age group was found to be significantly associated with the usage of sanitary latrines. $(p=0.016)$. Sanitation practice was found to be significantly related to awareness of the mode of spread of disease $(\mathrm{p}<0.001)$.

\section{CONCLUSIONS}

Behavioural change communication is required to motivate people to break the habit of open defecation and remove the barriers which limit the use of sanitary latrines.

\section{KEY WORDS}

Open Defecation, Rural, Drainage, Sanitation Practice
Corresponding Author:

Prashant Kumar Bajpal,

Department of Community Medicine, Academic Block, UPUMS, Saifai,

Etawah-206130, Uttar Pradesh, India.

E-mail: prashantbajpaillrm@gmail.com

DOI: $10.14260 /$ jemds/2020/325

Financial or Other Competing Interests: None.

How to Cite This Article:

Mathew DJ, Kumar S, Jaiswal K, et al. Awareness and practices of sanitary latrine usage and environmental cleanliness in rural Etawah, Uttar Pradesh. J. Evolution Med. Dent. Sci. 2020;9(18): 1490-1493, DOI:
Submission 11-02-2020,

Peer Review 16-04-2020,

Acceptance 23-04-2020,

Published 04-05-2020. 


\section{BACKGROUND}

Open defecation refers to the practice in which people go out in fields, bushes, forests, open bodies of water, or other open spaces rather than using a toilet to defecate. ${ }^{1}$ The Sustainable Development Goal 6 targets to achieve adequate and equitable sanitation and hygiene for all and ending open defecation by 2030. The 2017 JMP report of WHO/UNICEF showed that 892 million people around the world still practice open defecation. ${ }^{2}$ This marks an improvement from the 1.1 billion figure in 2012, of which $59 \%$ was contributed by India. ${ }^{3}$ The NFHS-4 (2015-16) estimates that 39 percent of households practiced open defecation in India, which marks an improvement from 55\% reported in NFHS-3 (2005-06). ${ }^{4}$

The Swachta Status Report 2016 states that the majority of people in India (52.1\%) practiced open defecation; $24.4 \%$ of households disposed of garbage in the nearby agricultural field, while $15.1 \%$ threw garbage around the house. ${ }^{5}$ Open defecation has dire consequences on the health of the population, contributing to child stunting, diarrhoeal diseases, and worm infestations. ${ }^{6,7}$ It also poses a threat to the safety of women and girls, infringes on personal dignity and violates the fundamental right to sanitation. The Swachh Bharat Mission in India was an ambitious toilet construction project initiated to bridge this gap in hygiene, to help create a clean and open defecation free nation.

The National Sample Survey 2018 reported that $71.3 \%$ of households in rural areas had access to sanitary latrine. Of those having household latrines, $3.5 \%$ of members never used it. ${ }^{8}$ Construction of toilets does not always translate into the usage of toilets in rural areas. ${ }^{9}$ The habit of defecating in the open environment without walls taking in 'fresh air', inadequate structure and design of subsidized latrines, lack of water supply in the toilet, the sense of impurity that the latrine pit was inside the home compound, long-standing habit of open defecation in elderly who were mostly inexorable, and women viewing open defecation as a time of socializing with friends after a day's work were some reasons for non-usage of sanitary latrine. ${ }^{10}$ Thus, there is the need for behaviour change communication in the community, by creating awareness about hygiene and cleanliness, to change the long-ingrained habit of open defecation. This study was aimed to study the awareness and practices of the rural population regarding sanitary latrine usage and environmental sanitation.

\section{METHODS}

This was a community-based cross-sectional study, conducted in four purposively selected villages, having a total of 1712 households, belonging to the field practice area of the Department of Community Medicine. Of the 1712 households, a sample of 150 households was purposively taken for the present study. The 150 households comprised 50 households each from the two large villages (having more than 500 households) and 25 households each from the two small villages (having less than 250 households). Every fifth household of a village was selected using the inclusion criteria, starting from a common point such as the school or general shop, until the desired sample size was reached. If the particular house was locked or the inclusion criterion was not met, then the next household was selected. Only those households were included whose residents were residing in the village for the past one year. Informed consent was taken from the participants of the study. One member from each household, preferably the head of the family, was interviewed personally, using a pre-designed semi-structured questionnaire and information was collected regarding their background characteristics, awareness and practices of sanitary latrine usage and environmental cleanliness. The questionnaire was pretested on 15 households of a nearby village which were not included in the study. Ethical clearance was taken from the University Ethical Committee.

\section{Statistical Analysis}

Data collected were entered in Microsoft Excel sheet and analyzed by the Statistical Package for Social Sciences (SPSS) version 24.0 (IBM Inc. Chicago, USA). Categorical variables were assessed using Chi-Square test and Fisher-Exact test. Statistical significance was considered for a p-value of less than 0.05 .

\section{RESULTS}

Out of the total participants $(n=150)$, majority were of the age group of 20-40 years ( $n=125,83.3 \%)$, while $16.7 \%(n=25)$ belonged to the age group of 40-60 years. The mean age of the participants was $33.1 \pm 9.86$ years. Most of the respondents were females (76.7\%), 37.3\% were illiterate and $74 \%$ were unemployed. The majority of the study subjects belonged to the lower middle socio-economic class $(73.3 \%)$ and lived in joint families (58.7\%).

The distribution of accessibility to sanitary latrine and sanitation practice is summarized in table 1 . While most participants (49.3\%) had sanitary latrine in their own house $4 \%$ shared latrines and $46.7 \%$ had no access to sanitary latrine. The most common reason for non-construction of latrine was that it was not being provided by the Government (40\%). But when asked about the practice, only $46 \%$ used sanitary latrine, while $54 \%$ practiced open-air defecation. The drainage system of most households of the study participants was of open pucca type (73.3\%). Most of the households of the participants disposed of garbage at a common dumping spot outside their homes (48.7\%), while $39.3 \%$ resorted to disposal at their own dumping spot, commonly in their own agricultural field.

Table 2 showed that the utilization of sanitary latrine was only $86.3 \%$, with various reasons being given for nonutilization. The most common reason for non-utilization was lack of water supply inside the latrine, which was complained of by all, followed by incomplete superstructure (54.5\%), lack of cleanliness (18.2\%), personal preference (18.2\%) and malfunctioning of the latrine $(9.1 \%)$

Most of the respondents were unaware that diseases can be caused by inadequate sanitation (55.3\%). Among those who were aware, the majority knew that loose stools could result from inadequate sanitation (79.1\%), while few were aware that worm infestation or typhoid could result from it. Around $94 \%$ of the respondents who were aware that 
diseases could be caused by inadequate sanitation also knew that flies could spread disease; fewer subjects were aware of the fact that contaminated food, contaminated water or unclean hands could act as a potential source of infection. (Table 3)

\begin{tabular}{|cc|}
\hline Characteristic & Frequency (\%) \\
Access to sanitary latrine & $74(49.3)$ \\
Sanitary latrine in own house & $6(4.0)$ \\
Shared latrine & $70(46.7)$ \\
No access & \\
Place of defecation & $69(46.0)$ \\
Sanitary latrine & $81(54.0)$ \\
Open air defecation & \\
Drainage system & $21(14)$ \\
Covered pucca & $110(73.3)$ \\
Open pucca & $19(12.7)$ \\
Open kuccha & \\
Garbage disposal & $59(39.3)$ \\
Own dumping spot & $73(48.7)$ \\
Community dumping spot & $18(12.0)$ \\
Indiscriminate throwing around the house & Table 1. Distribution of Participants According to Accessibility and \\
Practice of Sanitation and Environmental Cleanliness (N=150) \\
\hline
\end{tabular}

\begin{tabular}{|cc|}
\hline Characteristic & Frequency (\%) \\
Yes & $69(86.3)$ \\
No & $11(13.7)$ \\
Reason for non-utilization of sanitary latrine $(\mathbf{n}=\mathbf{8 0})$ & $6(54.5)$ \\
Lack of superstructure & $11(100.0)$ \\
Lack of water supply in sanitary latrine & $1(9.1)$ \\
Malfunctioning of latrine & $2(18.2)$ \\
Lack of cleanliness & $2(18.2)$ \\
Personal preference & Dation \\
\hline Table 2. Distribution of Participants According to Utilization of \\
Sanitary Latrine and Reasons for Non-Utilization \\
\hline
\end{tabular}

\begin{tabular}{|cc|}
\hline Characteristic & Frequency (\%) \\
Awareness whether disease can be spread by inadequate sanitation \\
Yes & $67(44.7)$ \\
No & $83(55.3)$ \\
Awareness about diseases spread due to inadequate sanitation* $(\mathbf{n = 6 7 )}$ & $53(79.1)$ \\
Loose stools & $5(7.5)$ \\
Typhoid & $22(32.8)$ \\
Worm infestation & $63(94.0)$ \\
Awareness of mode of spread of disease due to inadequate sanitation* & $(\mathbf{n}=\mathbf{6 7})$ \\
Flies & $21(31.3)$ \\
Contaminated food & $4(6.0)$ \\
Lack of hand hygiene & $6(9.0)$ \\
Contaminated water & \\
\hline Table 3. Distribution of Awareness of Diseases \\
Caused by Inadequate Sanitation \\
\hline
\end{tabular}

\begin{tabular}{|c|c|c|c|c|}
\hline \multirow{2}{*}{\multicolumn{2}{|c|}{ Characteristic }} & \multicolumn{2}{|c|}{$\begin{array}{c}\text { Sanitation practice } \\
\text { (no. \%) }\end{array}$} & \multirow{2}{*}{$\begin{array}{l}\text { Chi Sq. } \\
\text { Value, } \\
\text { P-Value }\end{array}$} \\
\hline & & $\begin{array}{l}\text { Sanitary } \\
\text { Latrine } \\
(n=69)\end{array}$ & $\begin{array}{c}\text { Open } \\
\text { Defecation } \\
(n=81)\end{array}$ & \\
\hline \multirow{2}{*}{ Age Group } & $\begin{array}{c}20-40 \text { years } \\
(\mathrm{n}=125)\end{array}$ & $52(41.6)$ & $73(58.4)$ & \multirow{2}{*}{$\begin{array}{l}\chi^{2}: 5.85 \\
p=0.016\end{array}$} \\
\hline & $\begin{array}{c}40-60 \text { years } \\
(\mathrm{n}=25)\end{array}$ & $17(68.0)$ & $9(32.0)$ & \\
\hline \multirow{2}{*}{$\begin{array}{l}\text { Awareness of the fact } \\
\text { that contaminated food } \\
\text { can cause spread of } \\
\text { disease in inadequate } \\
\text { sanitation practices }\end{array}$} & Yes $(n=21)$ & $17(81.0)$ & $4(19.0)$ & \multirow[b]{2}{*}{$\begin{array}{r}\chi^{2}: 12.30 \\
p<0.001\end{array}$} \\
\hline & No $(n=46)$ & $16(34.8)$ & $30(65.2)$ & \\
\hline \multicolumn{5}{|c|}{$\begin{array}{c}\text { Table 4. Association between Sanitation Practice with } \\
\text { Age and Awareness of Mode of Spread of Disease }\end{array}$} \\
\hline
\end{tabular}

Among the study population, the age of the participants was found to be significantly associated with sanitation practice. $(\mathrm{p}=0.016)$ Majority of the respondents of the age group of 40-60 years used sanitary latrine (68\%), as opposed to $41.6 \%$ of participants of the age group of $20-40$ years. Sanitation practice was found to be significantly related to awareness of the mode of spread of disease. $(p<0.001)$ Majority of those who were aware that contaminated food due to inadequate sanitation could cause the spread of disease $(81 \%)$ used sanitary latrines, while a majority of those who were unaware practiced open-air defecation (65.2\%). (table 4).

\section{DISCUSSION}

In the current study, most of the participants were females, and hence unemployed; $37.3 \%$ were uneducated. Panda PS et al., in their study reported that majority of participants were males $(92.3 \%)$ and hence two-thirds were employed in contrast to the present study; $31.6 \%$ were illiterate, similar to the present study. ${ }^{11}$ Around $87 \%$ lived in nuclear families and majority belonged to lower class (57.4\%), as opposed to the current study in which majority lived in joint families (58.7\%) and belonged to lower middle class (73.3\%)

Panda PS et al reported in their study a $23.2 \%$ prevalence of open defecation, which was lower than in the current study (54\%). ${ }^{11}$ The most common reason for not constructing latrine at own house was lack of interest (58.7\%), in contrast to the current study, in which participants blamed the Government for not providing it. Similarly, Anuradha R et al reported in their study the prevalence of open defecation as $33.1 \%$, with $61.1 \%$ claiming lack of interest to be the cause of non-construction of latrines. ${ }^{12}$ Routary et al found in his study that the most common reason for non-utilization of sanitary latrine was due to inadequate design and incomplete construction; in the current study, non-utilization due to incomplete superstructure was 54.5\%. ${ }^{10}$

According to Swachta Status Report 2016, 36.7\% of villages had pucca drainage and $19 \%$ of villages had kuccha drainage for wastewater. The current study reported a higher percentage of pucca drainage (87.3\%), although mostly open and uncovered drainages. The Report observed that most of the households kept garbage at a specified place outside their own house, while $24.4 \%$ disposed it in a nearby agricultural field, 5.5\% households had a common dumping site and $15.1 \%$ threw around the house; in the current study, most households disposed of garbage at a common spot (48.7\%), $39.3 \%$ in their agricultural fields and $12 \%$ practiced indiscriminate throwing. ${ }^{5}$ The larger figures in the present study might be due to the smaller sample involved.

The awareness of diseases caused by inadequate sanitation was lower in a study by Panda PS et al (34.8\%) compared to the current study (44.7\%). ${ }^{11}$ Those who were aware of the fact that contaminated food due to inadequate sanitation could spread disease tended to use sanitary latrines. The finding that usage of sanitary latrines was more among higher age group was contradictory to the finding by Routary et al, in which adult men and older men were accustomed to going to the fields for defecation early in the morning. ${ }^{10}$ This difference might be due to the fact that there were mostly females in the higher age group.

\section{CONCLUSIONS}

The current study shows a high prevalence of open-air defecation of $54 \%$, non-utilization of sanitary latrines and decreased awareness of the consequences of open-air 
defecation. Behavioural change communication is required to motivate people to break the habit of open defecation and remove the barriers which limit the use of sanitary latrines. As toilets are being constructed at a fast pace in the country through the Swachh Bharat Abhiyan, emphasis must also be given to quality and utilization, so that the menace of open defecation will be eliminated.

\section{REFERENCES}

[1] Eliminate Open Defecation. UNICEF [cited 2019 Dec 21]. https://unicef.in/Whatwedo/11/Eliminate-OpenDefecation

[2] World Health Organization, UNICEF. Progress on drinking water, sanitation and hygiene: 2017 update and SDG baselines. 2017 [cited 2019 Dec 22]. http://www.who.int/water_sanitation_health/publicatio ns/jmp-2017/en/

[3] WHO. Fast facts. WHO. [cited 2019 Dec 22]. http://www.who.int/water_sanitation_health/monitorin g/jmp2012/fast_facts/en/

[4] International Institute for Population Sciences (IIPS) and ICF. 2017. National Family Health Survey (NFHS-4), 2015-16: India. Mumbai: IIPS. http://rchiips.org/NFHS/NFHS-4Reports/India.pdf.

[5] National Sample Survey Office. Swachhta Status Report 2016. New Delhi: Ministry of Statistics and Programme Implementation, Government of India. 2016. http://mospi.nic.in/sites/default/files/publication_repo rts/Swachhta_Status_Report\%202016_17apr17.pdf

[6] Rah JH, Cronin AA, Badgaiyan B, et al. Household sanitation and personal hygiene practices are associated with child stunting in rural India: a cross-sectional analysis of surveys. BMJ Open 2015;5(2):e005180.
[7] Kumar A, Das KC. Drinking water and sanitation facility in India and its linkages with diarrhoea among children under five: evidences from recent data. Int J Humanit Soc Sci Res 2014;3(4):50-60.

[8] National Sample Survey Office. Drinking water, Sanitation, Hygiene and Housing condition in India. New Delhi: Ministry of Statistics and Programme Implementation, Government of India. 2018. [cited 2019 Oct 23]

http://www.mospi.gov.in/sites/default/files/publicatio n_reports/Report_584_final_0.pdf

[9] Water and Sanitation Program. World Bank. A Decade of the Total Sanitation Campaign: Rapid Assessment of Processes and Outcomes. New Delhi: World Bank, 2011 [cited 2019 Oct 23]. https://www.wsp.org/sites/wsp/files/publications/WS P_India_TSC_Report_Vol_1_Press.pdf

[10] Routray P, Schmidt WP, Boisson S, et al. Socio-cultural and behavioural factors constraining latrine adoption in rural coastal Odisha: an exploratory qualitative study. BMC Public Health 2015;15(1):880.

[11] Panda PS, Chandrakar A, Soni GP. Prevalence of open air defecation and awareness and practices of sanitary latrine usage in a rural village of Raipur district. Int J Community Med Public Health 2017;4(9):3279-82. https://www.ijcmph.com/index.php/ijcmph/article/do wnload/1671/1413

[12] Anuradha R, Dutta R, Raja JD, et al. Role of community in Swachh Bharat Mission. Their knowledge, attitude and practices of sanitary latrine usage in rural areas, Tamil Nadu. Indian J Community Med 2017;42(2):107-10. 